Evaluating the prevalence measles virus IgM antibodies for under 2 years children in Diayala governorate

Ibtihal Hameed Mohsin Al-Ezzi

\title{
Evaluating the prevalence measles virus IgM antibodies for under 2 years children in Diayala governorate.
}

\author{
Ibtihal Hameed Mohsin Al-Ezzi \\ Diayala University- College of science- Department of Biology- Iraq \\ Received: 1 April 2016 \\ Accepted: 11 May 2016
}

\begin{abstract}
$\underline{\text { Abstract }}$
The goal of present study was to evaluating the prevalence of measles virus (MV) immunoglobulin $\mathrm{M}$ antibodies in children under two year. This study was conducted from the period from 1 / 5 / 2015 to 30/ 2 / 2016. It included; Sera of 163 from children, 91(55.8\%) from children aged (0-8) months and 72(44.2\%) from children aged (9-23) months were collected from Al-Batool teaching Hospital. Detection of anti-measles $\operatorname{IgM}$ antibody was done by Enzyme - linked immunosorbent assay in the Center Public Health Laboratory. The seroprevalence of measles virus IgM obtained in this study 35(21.5\%) were anti-MV IgM positive and 128(78.5\%) children were anti-MV IgM negative. Additionally positivity of measles virus infection (28.2\%) among children aged (0-8) months, and (12.5\%) among children aged (9-23) months .Moreover the sero-prevalence of IgM was 5 (10\%) among males and $30(26.5 \%)$ among females. Furthermore, the prevalence of IgM 5(6.9\%) among vaccinated children, on other hand 30(32.9\%) among unvaccinated children. As well as, the Positivity of IgM $12(11.2 \%)$ in Children of mothers with vaccinated or a past history of measles, While 23 $(41 \%)$ among children of mothers with unvaccinated or no a past history of measles. Finally, the prevalence of IgM was 2(2.6\%) in children who were breast feeding, but 33(37.9\%) among non-breastfeeding children. In conclusion, the prevalence of anti-MV IgM was higher among aged (0-8) months. For the more, the prevalence of $\operatorname{IgM}$ was higher among females. Additionally prevalence it's higher among unvaccinated children. While prevalence its higher among children of mothers with unvaccinated or no history of measles. Finally, the prevalence it's higher among non- breastfeeding children.
\end{abstract}


Evaluating the prevalence measles virus IgM antibodies for under 2 years children in Diayala governorate

Ibtihal Hameed Mohsin Al-Ezzi

Key words: Measles virus (MV), IgM, ELISA, under 2 years Children

تحديد انتشار الضدات النوعية IgM لقيروس الحصبة المختلطة للأطفال تحت عمر 2 سنة في محافظة

\author{
ديالى \\ ابتهال حميد محسن العزي \\ جامعة ديالى_كلية العلوم - قسم علوم الحياة
}

\title{
الخلاصة
}

الهدف من الدر اسة الحالية هو تقيم انتشار الضدات النوعية IgM لفيروس الحصبة المختلطة (Measles virus) بين الأطفال تحت عمر سنتين .أجريت الدراسة الحالية لفترة من 1|5|2015 إلى 30|2|2016 ،حيث نم جمع 163 عينة دم من الأطفال وكانت الأعمار متر اوحة من (9-23)شهر وبعدها قسمت إلى مجموعتين المجموعة الأولى من (0-8)شهر وبنسبة

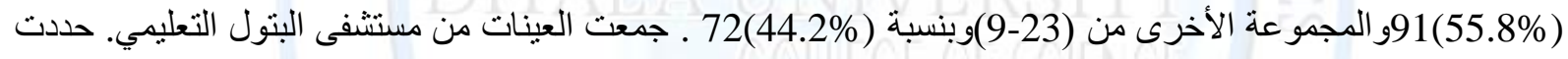
الضدات النوعية IgM لفيروس الحصبة باستخدام تقنية الأنزيم المرتبط المناعي (الاليزا) في مختبر الصحة المركزي .

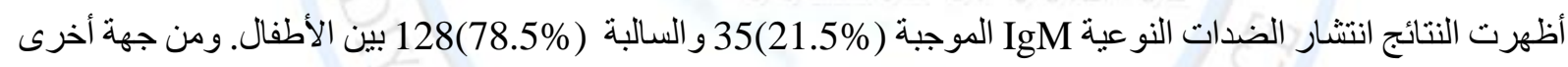
فان معدل انتشار المرض بين الأطفال الذين أعمار هم مابين (-8-8) وبنسبة 28.2\% أعلى من الأطفال الذين أعمار هم

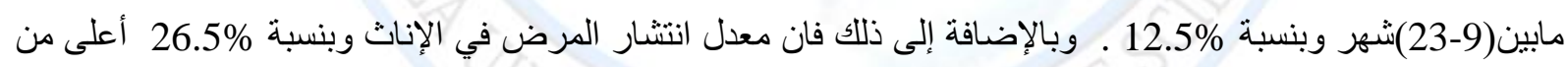
الذكور وبنسبة 10\% ـ ومعدل انتشاره بين الأطفال غبر ملقحين وبنسبة 32.9\% أعلى منه في الأطفال الملقحين وبنسبة

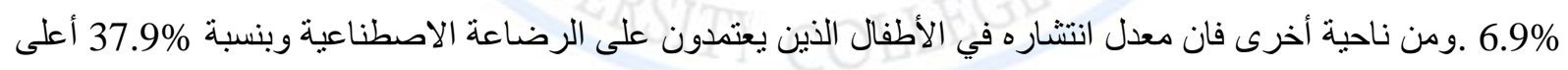

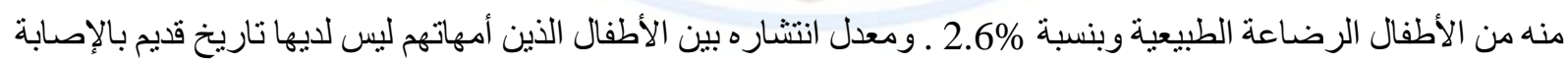
بمرض الحصبة و غير ملقحات ضد المرض وبنسبة 41\% أعلى من الأطفال الذين أمهاتهم لديها تاريخ قديم بالإصابة وملقحات

الكلمات المفتاحية : فيروس الحصبة،الاليز ا،الأطفال تحت عمر 2 سنة،الضدات النوعية 


\section{Evaluating the prevalence measles virus IgM antibodies for under 2 years children in Diayala governorate}

\section{Ibtihal Hameed Mohsin Al-Ezzi}

\section{Introduction}

Measles remains a major public health problem, Measles viruses is the cause of measles diseases ,measles virus (MV)is belongs to the family Paramyxoviridae, of the genus Morbillivirus .This virus is a single stranded RNA(SSRNA molecule of negative sense),Spherical, enveloped consists of haemagglutinin protein and the fusion embedded in the lipid bilayer . $(1,2)$.

Measles is an antigenically stable virus . There is one serotype only and there are very little differences between different isolates (3). Measles is more wide spread distribution in developing countries $(4,5,6)$. The World Health Organization (WHO) report 30,000,000 new cases of measles in developing countries $(7,8,9)$.Measles has been eliminated in western counties by aggressive style (10,11). In Africa 220,000 cases of measles among children less than five years. (12). The disease is characterized by an incubation cycle of 10-11 days, the patient enters the prodromal, fever, malaise ,catarrh of upper respiratory tract ,sneezing , conjunctivitis and cough (13). Kopliks spots, which are path gnomonic are measles, appear on the buccal and labial mucosa opposite the lower molars .It is appear about 4 days after exposure and starts behind the ears and on the forehead (14). Measles is transmitted principally from person to anyone by big respiratory droplets, but can as well be broaden by aerosolized droplets, as well as adjacent personal contact or direct contact with nasal or throat secretions from ill persons(1). discovery of IgM antibodies to Measles viruses is as a rule performed by Enzyme - linked immunosorbent assay (ELISA) and the indirect immunofluorescence test (IIFT),The measles IgM ELISA is more speedy and responsive for serological analysis of measles disease than other tests(15), and finding of measles virus (MV).

RNA by nested real-time PCR(16). goal of present study was to evaluating the prevalence of measles virus (MV) immunoglobulin M antibodies in children under two year 


\section{Evaluating the prevalence measles virus IgM antibodies for under 2 years} children in Diayala governorate

\section{Ibtihal Hameed Mohsin Al-Ezzi}

\section{Material and methods}

The present study was conducted in Diayala governorate for the period from 1 / 5 / 2015 to 30/ 2 / 2016. It included; 163 sera sample from children under 2 years ,91 as of children (08)months and 72 as of children aged (9-23) months were collected from Al-Batool teaching Hospital. Detection of IgM antibodies to Measles viruses was done using ELISA techniques in the Center Public Health Laboratory .

\section{Collection of serum specimens}

From each personality in this study, $2 \mathrm{ml}$ of blood was strained by vein penetrate by throwaway syringes. The blood was located in plastic disposable tubes; it was gone to place at room temperature $\left(20-25^{\circ} \mathrm{C}\right)$ to let it to clot, then the sera was separated by centrifugation $10000 \mathrm{rpm}$ for 5 minutes and stored at $-20^{\circ} \mathrm{C}$ till examination. The specimens were transferred to the Virology Unit / Public Health Laboratory in Baquba

for discovery of $\operatorname{IgM}$ antibodies to Measles viruses in serum specimens through ELISA test. All sera specimens and reagents were allowable to place at room temperature previous to employ in the analysis.

\section{Detection of Measles virus}

Measles virus IgM (serum) ELISA test: This test was performed using commercially available kit (Measles IgM ELISA Test Kit). Reactive results were indicated by the absorbance reading of 1.1 and above, while the non-reactive results were indicated by the absorbance reading less than 0.9 .

Principle test: The IgM antibodies to Measles viruses EIA analysis Kit is a solid stage enzyme immunoassay accorded on indirect standard used for the qualitative and quantitative discovery of IgM antibodies to Measles viruses in human plasma or serum. The micro well plate is covered with MV antigen. During testing, the specimen diluents and the specimens are additional to the antigen covered micro well plate and then incubated. If the specimens contain IgM antibodies to MV, it well binds to the antigens covered on the micro well plate to form immobilized antigen-MV IgM antibody complexes. If the specimens do not contain IgM 


\section{Evaluating the prevalence measles virus IgM antibodies for under 2 years children in Diayala governorate}

\section{Ibtihal Hameed Mohsin Al-Ezzi}

antibodies to MV, the complexes will not be produced. After first incubation, the micro well plate is washed to take away unbound materials. The enzyme-conjugated anti-human IgM antibodies are additional to micro well plate and then incubated. The enzyme-conjugated antihuman IgM antibodies will bind to immobilized antigen-MV IgM antibody complexes present. After the second incubation, the micro well plate is washed to take away unbound materials. Substrate A and substrate B are additional and then incubated to create a blue color indicating the amount of MV IgM antibodies here in the specimens. Sulfuric acid solution is added to the micro well plate to stop the reaction a color alter from blue to yellow. The color strength, which corresponds to the amount of MV IgM antibodies found in the specimens, is measured with a micro plate reader at $450 / 630700 \mathrm{~nm}$ or $450 \mathrm{~nm}(17)$.

\section{$\underline{\text { Results and Discussion }}$}

The evaluated of IgM antibodies to Measles viruses obtained in this study was $35(21.5 \%)$, prevalence of measles virus infection (28.2\%) among aged (0-8) months, and (12.5\%) among aged (9-23) months (Table 1).

Table.1 Measles infection among the different age groups of children

\begin{tabular}{|c|c|c|c|}
\hline \multirow{2}{*}{ Age group (mounth) } & \multicolumn{2}{|c|}{ Suspected } & \multirow{2}{*}{ Measles positive } \\
\cline { 2 - 3 } & Number & $\%$ & \\
\hline$(0-8)$ month & 91 & 55.8 & $26(28.2 \%)$ \\
\hline$(9-23)$ month & 72 & 44.2 & $9(12.5)$ \\
\hline Total & 163 & 100 & 35 \\
\hline
\end{tabular}

In addition to, Table 2 shows the gender distribution of the prevalence of MV infection 5 (10\%) among males and $30(26.5 \%)$ among females. 
Evaluating the prevalence measles virus IgM antibodies for under 2 years children in Diayala governorate

Ibtihal Hameed Mohsin Al-Ezzi

Table.2 Distribution of infected according to gender

\begin{tabular}{|c|c|c|c|}
\hline \multirow{2}{*}{ Sex } & \multicolumn{2}{|c|}{ Suspected } & \multirow{2}{*}{ Measles positive } \\
\cline { 2 - 3 } & Number & $\%$ & \\
\hline Female & 113 & $69.3 \%$ & $30(26.5)$ \\
\hline Male & 50 & $30.7 \%$ & $5(10 \%)$ \\
\hline Total & 163 & 100 & 35 \\
\hline
\end{tabular}

prevalence of $\operatorname{IgM}$ antibodies to measles virus in children in relative to their vaccination $5(6.9 \%)$ among vaccinated children , and 30(32\%) among unvaccinated children Table3 .

Table.3 prevalence of IgM antibodies to measles virus among children in relative to their vaccination

\begin{tabular}{|c|c|c|c|}
\hline \multirow{2}{*}{ Vaccination } & \multicolumn{2}{|c|}{ Suspected } & \multirow{2}{*}{ Measles positive } \\
\cline { 2 - 3 } & Number & $\%$ & \\
\hline Vaccinated & 72 & $44.2 \%$ & $5(6.9 \%)$ \\
\hline Unvaccinated & 91 & $55.8 \%$ & $30(32.9 \%)$ \\
\hline Total & 163 & 100 & 35 \\
\hline
\end{tabular}

Table 4.show prevalence ofIgM anyibodies measles virus in Children of vaccinated and mothers with a past history of measles 12 (11.2\%), and 23 (41\%) among children of unvaccinated and mothers with no a past history of measles.

Table.4 prevalence of IgM antibodies measles virus among children in relative to their vaccinated mothers and measles a past history of mothers.

\begin{tabular}{|c|c|c|c|}
\hline Children vaccinated \& a past & \multicolumn{2}{|c|}{ Suspected } & \multirow{2}{*}{ Measles positive } \\
\cline { 2 - 3 } history of measles mothers & Number & $\%$ & \\
\hline $\begin{array}{c}\text { vaccinated mothers \& a past } \\
\text { history of measles mothers }\end{array}$ & 56 & $34.4 \%$ & $12(11.2 \%)$ \\
\hline $\begin{array}{c}\text { unvaccinated mothers \&non } \\
\text { past history of measles mothers }\end{array}$ & 107 & $65.6 \%$ & $23(41 \%)$ \\
\hline Total & 163 & 100 & 35 \\
\hline
\end{tabular}




\section{Evaluating the prevalence measles virus IgM antibodies for under 2 years} children in Diayala governorate

Ibtihal Hameed Mohsin Al-Ezzi

Table 5.The prevalence of Igm antibodies MV in children who were breast feeding 2(2.6\%), and 33(37.9\%) among non- breastfeeding children.

Table.5 prevalence of IgM antibodies to measles virus among children in relative to their breast feeding

\begin{tabular}{|c|c|c|c|}
\hline \multirow{2}{*}{ Type of feeding } & \multicolumn{2}{|c|}{ Suspected } & \multirow{2}{*}{ Measles positive } \\
\cline { 2 - 3 } & Number & $\%$ & \\
\hline Breast feeding & 76 & $53.4 \%$ & $2(2.6 \%)$ \\
\hline Not Breast feeding & 87 & $46.6 \%$ & $33(37.9 \%)$ \\
\hline Total & 163 & $100 \%$ & 35 \\
\hline
\end{tabular}

Measles leftovers a most important health problem worldwide, particularly in developing countries. It is dependable for an estimated 420,000 yearly deaths worldwide among children fewer than five years of age (14). while the number of reported cases has noticeably decreased in a lot of countries as the widespread utilize of the approved vaccine, outbreaks happen not only in unvaccinated subjects but too in extremely vaccinated populations (18). The foreword of the measles vaccine in the 1960s led to a considerable decrease in the occurrence rates of measles and its complications in developed countries. However, measles still to cause important morbidity even in areas where the vaccine is obtainable, typically because of imperfect exposure, which joint with the elevated infection of the virus, allows for its long-term spread, occasionally in outbreak proportions (11). This study was calculated to determine the prevalence of measles virus (MV) antibodies in children (0-23)months. This study was included 163 children under two year, In this study the occurrence of MV establish in children aged ( $0-8)$ months $(28.2 \%)$ is higher than occurrence in previous studies $(6.5 \%)$ reported for Kaduna State in Nigeria (19), and (7.0\%) reported Akwa Ibom State ( 20), and (6\%) reported in Maiduguri, Borno State (21).This early appearance of measles has been credited to declining maternal antibodies, particularly in the location where protection is from vaccination not normal infection (21). The frequency of (12.5\%) was obtained in children aged (9-23) months, in this study is minor than frequency in previous studies $(61.6 \%)(19,22)$, and $30.2 \%$ reported in Akwa Ibom State (23) 32.2\% among adult children in Giwa, (22), but agreement with 15.6\% 


\section{Evaluating the prevalence measles virus IgM antibodies for under 2 years children in Diayala governorate}

\section{Ibtihal Hameed Mohsin Al-Ezzi}

reported in another study as of Southwestern Nigeria (24). The cause for the practical differences may be accelerated measles manage actions, including better routine vaccination exposure, provision of a second dose of measles vaccine as part of additional immunization actions in certain countries of the world, and may be credited to the significance and perseverance of important establishment in ensuring improved measles vaccine exposure in their area (25).In this study, females were seen to be more vulnerable to measles infection than their male counterparts, this result is agreement with previous studies $(19,23)$, and in Bolivia. $(23,24,26)$, but disagrees with the work of Chechet et al. $(4,26)$ Measles prevalence was minor in children were vaccinated $(6.9 \%)$ than in unvaccinated children $(32 \%)$, this study agreement with more studies $(19,27,6),(28,29,4,1)$. Measles frequency was low rank recorded for vaccinated children may reveal vaccine not a success as well as effectiveness of vaccination. Problems with storage, transportation, and preservation of a icy chain system can without difficulty influence the potency of vaccines in developing nations (27). The frequency of MV was elevated in children who were not breast feeding (37.9\%) than in breastfeeding children $(2.6 \%)$,this study is in agreement with previous studies $(30,31)$, the low prevalence among breastfeeding children may be due to a elevated rank of antibodies, as well as some probiotics contained in breast milk that confer immunity in these children, transferred antibodies, human breast milk is consideration to play an essential role in safety of little infants from infections(32,33) .Human milk is affluent in defensive proteins, counting secretary IgA (sIgA).The frequency of measles in children of unvacciation and mothers with non a past history of measles (41\%) higher than children of vaccination and mothers with a past history of measles (11.2\%), this agreement with previous studies by AE Olaitan,etal. $(19,34,35)$.This low observed occurrence in children of vaccination and mothers with a past history of measles be able to explained through the information that these mothers have naturally acquired protection against measles, which provides passive defense to their infants (36) . The attendance of $\operatorname{IgM}$ antibodies to $\mathrm{MV}$ in serum is analytic of innate measles disease or vaccination. However, in infants fewer than nine months of age, these antibodies usually reproduce placental antibodies transferred from the mother to the fetus (37). 
Evaluating the prevalence measles virus IgM antibodies for under 2 years children in Diayala governorate

Ibtihal Hameed Mohsin Al-Ezzi

\section{References}

1. Perry RT, Halsey NA. The clinical significance of measles: a review. J Infect Dis. (2004);189(Suppl 1):S4-S16.

2. Rima BK, Duprex WP. Morbilliviruses and human disease. J Pathol 208 (2006) ;199214

3. Adetunji OO, Olusola EP, Ferdinad FF, Olorunyomi OS, Idowu JV, Ademola OG. Measles among hospitalized Nigerian children. Internet J Pediatr Neonatol. 2007;7:29

4. Karimi A, Arjomandi A, Alborzi A, Rasouli M, Kadivar MR, Obood B, Pourabbas B. Prevalence of measles antibody in children of different ages in Shiraz, Islamic Republic of Iran. East Mediterr Health J 10 (2004); 468-473.

5. Ovsyannikova IG, Jacobson RM, Vierkant RA, et al. Associations between human leukocyte antigen (HLA) allele and very high levels of measles antibody following vaccination. Vaccine (2004);22:1914-20.

6. Bilkis MD, Barrero PR, Mistchenko AS. Measles resurgence in Argentina:1997-8 outbreak. Epidemiol Infect. 2000;124:289-93.

7. Hogg GG, Darlington RJ, Hogg KG, Lester R. Measles immunity and immunisation status in Australian children 1 to 4 years of age. J Paediatr Child Health 42 (2006); 165169.

8. Ota MO, Moss WJ, Griffin DE. Emerging diseases: measles. J Neurovirol 11 (2005); 447-454.

9. Bryce J, Boschi-Pinto C, Shibuya K, Black RE, and the WHO Child Health Epidemiology Refrence Group, 2005. WHO estimates of the causes of death in children. Lancet 365: 1147-1152.

10. De Barros EN, Silva EM. Epidemiologic surveillance of measles and rubella in Campinas (SP),Brazil: the reliability of the data. [Article in Portuguese] Rev Panam Salud Publica 19 (2006); 172-178.

11. Papania MJ, Orenstein WA. Defining and assessing measles elimination goals. J Infect Dis. (2004);189(Suppl 1):S23-S26. 


\section{Evaluating the prevalence measles virus IgM antibodies for under 2 years} children in Diayala governorate

\section{Ibtihal Hameed Mohsin Al-Ezzi}

12. Ceylan A, Ertem M, Korukluoglu G, Acemoglu H, Kara IH, Erten PG, Arslan C, Ay ME. An epidemic caused by measles virus type D6 in Turkey. Turk J Pediatr 47(2005); 309-315.

13. Smith TC. Measles vaccine doesn't cause SSPE. Aetiology (2006).

14. Cutts FT, Steinglass R. Should measles be eradicated. Br Med J 316 (1998); 765-767.

15. Roodbari F, Roustai MH, Mostafaie A, Soleimanjdahi H, Foroshani RS, Sabahi F. Development of an enzyme-linked immunosorbent assay for immunoglobulin M antibodies against measles

16. Pannuti CS, Morello RJ, Moraes JC, Curti SP, Afonso AM, Camargo MC, et al. Identification of primary and secondary measles vaccine failures by measurement of immunoglobulin $\mathrm{G}$ avidity in measles cases during the 1997 Sao Paulo epidemic. Clin Diagn LabImmunol. 2004;11(1):119-22.

17. Naing L, Winn T, Rusli BN. Practical issues in calculating the sample size for prevalence. Studies Archives of Orofacial Sciences. 2006;1:9-14 .

18. Poland GA, Jacobson RM. Failure to reach the goal of measles elimination. Apparent paradox of measles infections in immunized persons. Arch Intern Med 1994;154:181520.

19. AE Olaitan, EE Ella, and JB Ameh . Comparative seroprevalence of measles virus immunoglobulin $\mathrm{M}$ antibodies in children aged 0-8 months and a control population aged 9-23 months presenting with measles-like symptoms in selected hospitals in Kaduna State . Int J Gen Med. 2015; 9: 101-108.

20. Chukwuemeka AU, Hycienth PA. The impact of declining vaccination coverage on measles control: a case study of Abia State Nigeria. Pan Afr Med J.(2013);15:105.

21. Ahmadu BU, Mava Y, Ambe JP, Abdallah JA, Ovansa EO. Predicting changing measles epidemiology in an urban West African population. Ann Trop Med Public Health. 2013;6:179-182.

22. Chechet J, Ella EE, Ige SO. Seroprevalence of measles IgM in children 5-12 years from selected primary schools in Giwa Local Government Area, Zaria, Kaduna State. Scientific Journal of Microbiology. (2014);3:19-24. 


\section{Evaluating the prevalence measles virus IgM antibodies for under 2 years} children in Diayala governorate

\section{Ibtihal Hameed Mohsin Al-Ezzi}

23. Bassey EB, Moses AE, Udo SU, Umo AN. The impact of immunization control activities on measles in Akwa Ibom State. Online J Health Allied Sci. 2010;9:3.

24. Omilabu SA, Oyefolu AO, Ojo OO, Audu RA. Potency status and efficacy of the measles vaccine administered in Nigeria: a case study of three EPI centers in Lagos, Nigeria. Afr J Med Sci. (1999);28:209-212.

25. Manirakiza A, Kipela JM, Sosler S, Daba RM, Vasilache IG. Seroprevalence of measles and natural rubella antibodies among children in Bangui, Central African Republic. BMC Public Health. (2011);11:1471-2458.

26. Tharmaphornpilas $P$, Yoocharean $P$, Rasdjarmrearnsook A, Theamboonlers A, Yong P. Seroprevalence of antibodies to measles, mumps, and rubella among Thai population: evaluation of measles/MMR immunization programme. J Health Popul Nutr. (2009);27:80-86.

27. Kouomou DW, Nerrienet E, Mfoupouendoun J, Tene G, Whittle H, Wild TF. Measles virus strains circulating in Central and West Africa: geographical distribution of two B3 genotypes. J Med Virol. 2002);68:433-440.(

28. Centers for Disease Control and Prevention (CDC). Measles outbreak-Netherlands, April 1999-January 2000. MMWR Morb Mortal Wkly Rep (2000);49:299-303.

29. Azizi F, Janghorbani M, Hatami H. Epidemiolgy and control of common disorders in Iran. Endocrine and Metabolic Research Center of Shaheed Beheshti University of Medical Sciences. EshtiaghPublisher, 2000; pp. 634-45.

30. Katona $\mathrm{P}$, Katona-Apte $\mathrm{J}$. The interaction between nutrition and infection. Clin Infect Dis. (2008);46:1582-1588.

31. Masuet-Aumatell C, Ramon-Torrell JM, Casanova-Rituerto A, Banqué Navarro M, Dávalos Gamboa Mdel R, Montaño Rodríguez SL. Measles in Bolivia: a honeymoon period. Vaccine.( 2013);31:2097-2102.

32. Hanson LA, Hahn-Zoric M, Berndes M, Ashraf R, Herias V, Jalil F, Butta TI, Laeeg A, Mattsby-Baltzer I. Breast feeding: overview and breast milk immunology. Acta Paediatr Jpn .( 1994); 36: 557-561. 
Evaluating the prevalence measles virus IgM antibodies for under 2 years children in Diayala governorate

Ibtihal Hameed Mohsin Al-Ezzi

33. Thomas JE, Austin S, Dale A, McClean P, Harding M, Coward WA, Weaver LT. Protection by human milk IgA against Helicobacter pylori infection in infancy. Lancet . (1993);42: 121.

34. Brugha R, Ramsay M, Forsey T, Brown D. A study of maternally derived measles antibody in infants born to naturally infected and vaccinated women. Epidemiol Infect Dis. (1996);117:519-524.

35. Nicoara C, Zäch K, Trachsel D, Germann D, Matter L. Decay of passively acquired maternal antibodies against measles, mumps and rubella viruses. Clinical Diagnostic Laboratory Immunology. (1999);6:868-871.

36. Tipples GA, Hamkar R, Mohktari-Azad T, Gray M, Parkyn G, Head C, Ratnam S. Assessment of immunoglobulin M enzyme immunoassays for diagnosis of measles. $\mathrm{J}$ Clin Microbiol.( 2003); 41: 4790-4792.

37. Weaver LT, Arthur HM, Bunn JE, Thomas JE. Human milk IgA concentrations during the first year of lactation. Arch Dis Child. (1998); 78: 235-239. 